\title{
Provincial-regional ANC politics in the Northern Cape: corruption or everyday informal practices?
}

\author{
Commonwealth Journal of Local Governance \\ Issue 19: December 2016 \\ http://epress.lib.uts.edu.au/ojs/index.php/cjlg
}

\author{
Thina Nzo \\ Centre of African Studies \\ University of Edinburgh \\ United Kingdom
}

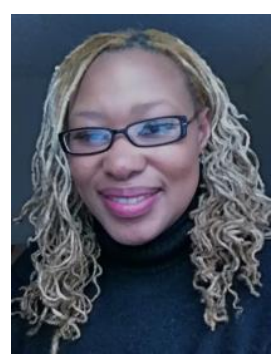

\begin{abstract}
Research over the last decade on local government in South Africa has highlighted that some municipal councils under the political leadership of the Africa National Congress (ANC) have shown weak political leadership, coupled with strong patronage systems, rent-seeking and corruption which have had an impact on the institutional functionality of municipalities in South Africa. Although patronage politics have been predominantly used to analyse the dynamics of post-apartheid local government ANC politics and councillor representation, this prevents us from understanding the representational focus of ANC councillors in decision-making processes. This paper offers an ethnographic insight into experiences of ANC councillors and the political complexities involved in council decision-making. Using ethnographic research, this paper will analyse how a political decision by the ANC provincial party, which was supported by the ANC regional party at local levelto erect a statue of Nelson Mandela in one of the municipalities in the Northern Cape - generated tensions amongst ANC councillors who strongly viewed their primary role as promoters of better 'service delivery' rather than approving the allocation of scarce municipal resources for erecting a statue. The paper reveals how the dominant presence of ANC sub-regional structures at local level contribute to the complex interaction of both ANC party political and municipal organisational rules and norms that influence and shape councillors' choices in decision-making.
\end{abstract}

\section{South African post-apartheid local government and ANC party politics}

In August 2016, the African National Congress (ANC) experienced steep decline in local government elections, and the ANC lost control of three key city municipalities (Johannesburg, Pretoria and Port Elizabeth) and many more local municipalities to a coalition of opposition parties such as the Democratic Alliance (DA) and Economic Freedom Fighters (EFF) due to voter apathy amongst ANC

(C) 2016 Thina Nzo. This is an Open Access article distributed under the terms of the Creative Commons Attribution 4.0 Unported (CC BY 4.0) License (https://creativecommons.org/licenses/by/4.0/), allowing third parties to copy and redistribute the material in any medium or format and to remix, transform, and build upon the material for any purpose, even commercially, provided the original work is properly cited and states its license. 
loyal supporters (see Independent Electoral Elections 2016). ${ }^{1}$ This paper has given particular attention to the ANC and its councillors as the ruling party with the majority of seats in council ${ }^{2}$ which has powers to appoint its own majority ANC councillors as members of the executive committee and committee chairs. Therefore the ANC as a dominant party in the council has the responsibility of shaping and determining the agenda of the council and the political and development landscape of the municipality.

However, the decline in ANC electoral support and control over municipal councils since 2006 portrays how the ANC as a liberation party in power is beginning to lose its hegemonic grip over electoral support at local government level (Schulz-Herzenberg 2007; Schulz-Herzenberg and Southall 2014). ${ }^{3}$ More specifically, the recent 2016 election outcomes provided further evidence to support Schulz-Herzenberg's conclusion that the ANC weakening voter support signifies a 'silent revolution' against the liberation party and decline in the quality of local democracy (2007, p. 114). Most analysts have heavily criticised the ANC party and its elected local representatives (in particular ward councillors and political office-bearers such as speakers, mayors and members of the municipal mayoral executive committee) for being embroiled in patronage and rent-seeking (see Staniland 2008; Ndletyana et al. 2014; Beresford 2014; Dawson 2014; Butler 2015; Butler and Southall 2015; Ndletyana 2015), neo-patrimonialism (Lodge 1998 and 2014) and corruption (Hyslop 2005; Mashele and Qobo 2014; Johnson 2015) that has led to decline in service delivery and failure of ANC councillors in carrying out their representational mandate.

Some scholars have argued that service delivery protest action observed in most municipalities signify the pathological failures (Atkinson 2007) and 'dysfunctionality' of developmental local government state (Ballard et al. 2006; Southall 2007; Pithouse 2015; Alexander 2010; Butler 2010; von Holdt et al. 2011; Pieterse and Van Donk 2013; Booysen 2015; Pernegger 2015). Peter Alexander notes that such community protest action resembles conflict between the state and society, which is symbolic of a "rebellion of the poor", arguing that while neo-capitalism has sustained massive inequalities in

1 See Independent Electoral Commission (2016), Municipal elections outcome, http://www.elections.org.za/content/Elections/Municipal-elections-results/. [Accessed August 2016]; The Guardian (5 August 2016), South Africa's local election shock down to anger and apathy, https://www.theguardian.com/world/2016/aug/05/anger-and-apathy-behind-south-africas-shock-local-election [Accessed November 2016]; SABC (5 August 2016), Voter turnout drops in 2016 local government elections, http://www.sabc.co.za/news/a/9fa2bc004dc1bd28be2bbf359257e443/Voter-turnout-drops-in-2016-localgovernment-elections-20160508. [Accessed November 2016].

2 Although the DA as the main opposition party has made inroads by increasing its voter support in the local government elections, it and the smaller parties - such as Congress of the People (COPE) and the EFF (breakaway groups of the ANC) - do not have a significant impact on the major practices and dynamics of local government council politics.

${ }^{3}$ Electoral support for the ANC has gradually declined from 64\% in 2006, 62\% in 2011 to 55\% in 2016, with the ANC receiving less than 50\% voter support in four out of eight metropolitan municipalities they previously controlled. The recent 2016 election outcomes provided further evidence to support Schulz-Herzenberg's conclusion that weakening support and absence from the ballot box signifies a 'silent revolution' which leads to a decline in quality of local democracy $(2007$, p. 114). 
South Africa, citizens have become weary of the "inadequacy of service delivery and self-seeking councillors who are not accountable to the electorate" (2010, pp. 25-40).

In this case, the question of state capacity to deliver services ${ }^{4}$ and community protest action have become a focus of commentary for many academics and analysts engaged in local government studies and ANC politics. Public administration scholars such as De Visser (2010) and Cameron (2010) who paid particular attention to the functionality of municipalities, have directed attention towards the inefficiencies of municipal bureaucracies, arguing that political appointments and ANC interference in the running of municipalities have promoted widespread bureaucratic incompetence and inefficiency. Here analysts and academics begin to question not only the capability of the state to deliver on its constitutional 'developmental' mandate (Butler 2010; Von Holdt 2010; Fine 2010) but also the way in which the ANC has managed to conflate the party with the state (Booysen 2015). ${ }^{5}$

While scholars are beginning to take more interest in local government research, which adds valuable insight to the understanding of the dynamics and challenges of local democracy, they have provided little insight about the complexities of representative local democracy to explain the everyday experiences of councillors in the process of council decision-making from the perspective of elected representatives using ethnography. In other words we know little about what happens behind the council chamber and the executive committee in order to understand how ANC councillors take decisions. This paper argues that although the concept of patronage politics has been predominantly employed by academics and scholars to analyse the ANC and state-society relationship at local government level in South Africa, it prevents us from understanding the complexities and nuances of how ANC councillors in particular, exercise their representational focus in council decision-making structures.

This paper is based on ethnographic fieldwork carried out in a local municipality ${ }^{6}$ in the Northern Cape Province between September 2014 and August 2015. The political executive sphere of the municipal organisation was the primary context for examining the dynamics of council decisionmaking processes by exploring the relationship between ANC mayoral executive member councillors and their ANC regional party officials, as well as other institutional actors such as senior managers. The organisational ethnographic study involved 'being there' (Rhodes et al. 2007; Rhodes 2007) by

\footnotetext{
${ }^{4}$ Even though councillors are not responsible for administering services to communities, representing the service delivery needs and interests of communities remains the core of their representational role and focus.

${ }^{5}$ The State of Local Governance in South Africa Report (COGTA 2009) resonates with some of the arguments made by Smoke (2003) affirming that ineffective decision-making and weak accountability (and where elected members do not understand their roles and powers) as a result of weak political opposition and civil society, have prevented the deepening of local democracy through decentralisation in Africa.

${ }^{6}$ Due to politically sensitive issues and practices encountered during my study which might be considered as politically out of the norm, I have opted not reveal the name of the municipality and gave the participants pseudonyms in order to protect their identity.
} 
shadowing the mayor ${ }^{7}$ (the political head of the municipal organisation) and observing councillors during committee and council meetings. This was supported by informal conversations with ANC councillors and conducting semi-structured one-to-one interviews and focus group interviews and analysis of documentation of council and committee meetings and decisions (Yin 1989; Babbie and Mouton 2001; Ritchies and Lewis 2003; Van Hulst 2008; Brewer 2004; Burawoy 2003; Ybema and Kamsteeg 2009; Thedvall 2006, 2013).

The paper stresses that the councillors do not operate in a vacuum; they operate in a political environment that is regulated by party political processes as well as institutional rules and procedures relating to their prescribed roles and responsibilities. Councillors' representation is also influenced by competing interests (Copus 2004) of the electorate as well as other state actors such as the administration and ANC party political structures, the latter either constraining or enabling councillors to carry out their representational mandate. Accordingly decision-making structures are potential sites of contestations and therefore permeated by tensions and conflicts between the prescribed roles and responsibilities and the real conduct of councillors and administrators. For Oliver (2011, pp. 202-203) using "sense-making" enables us to "understand how external factors and internal preferences, logics and ideals interplay within a particular context to define the enactment of representation".

\section{Representative local democracy and council decision-making}

This paper locates itself within debates on local representative democracy (Mill 1865; Pitkin 1967; Eulau 1978). Councillors are elected local representatives and therefore viewed as key mediators between the state and society. Although there is an expectation that councillors ought to have a parochial community/ward orientation towards representation (Copus 2004), however, their representational focus is fluid and interfaces between political management committee work, community constituency/ward work and party related activities (Heclo 1969). Decision-making is one of the key political management roles of councillors serving in the executive and other committees. This relates to deciding on what public goods to deliver, how to allocation and distribute resources, which methods to choose from to deliver public goods, and how to achieve social change (see Parsons 1995) as well as a financial oversight role to play in ensuring that municipal finances are distributed to society in a transparent and accountable manner (SALGA 2006). While the study of decision-making is underpinned by long-standing theories on decision-making such as rationale and incremental decision-making (see Lasswell 1956; Lindblom 1959), in the context of this paper, council decisionmaking in a councillor's world of party politics does not fit easily within such prescriptive decisionmaking theories and models.

\footnotetext{
${ }^{7}$ The mayor of the municipality granted access into the field. My constant engagement with the mayor prior to the fieldwork and professional networks I had with the ANC provincial party officials made it less difficult in terms of knowing whom to talk to in order to gain access. Personal and professional networks can be advantageous in establishing direct communication and gaining access to political elites and bureaucratic organisations.
} 
This paper thus draws on the literature that appreciates that council decision-making can be a messy process that involves consensus and political negotiation (Lindblom 1959) amongst various interested groups, giving rise to conflict and tensions. Different interests and popular power is realised through group activity (Dearlove 1973; Fung and Wright 2001) the working of the political parties each represents one of the many interests. This is grounded in Dahl's seminal 1956 study of power in relation to pluralism, where he argues that power in societies is widely distributed amongst different groups but not equally distributed, but rather sources of power unequally though widely distributed amongst individuals and groups in society. In this case, power is distributed amongst political actors, councillors and senior managers who influence decision-making.

\section{ANC party and state conflation}

The partisan system of local government in South Africa has given the ANC as a dominant party more political authority and presence in the activities of council and councillor representation. ANC party political mandates are also informed by the nature of councillors' relationship and connection with the ANC regional party structure at local level (Corina 1974), which suggests that councillors have the dual mandate of representing the interests of the party and community. There has been some considerable scholarly focus on how the ANC has created a compliant party-state, where lines between the party and state are often blurred. This is underpinned by the argument of how the ANC has managed to use the liberation discourse to exert its hegemony and power over the levers of power in the state apparatus as a dominant party (Giliomee and Simkins 1999; Bompani 2006; Dorman 2006; Booysen 2015; Butler 2009, 2015; Suttner 2009). These scholars and commentators have raised criticism and concerns on how the ANC has managed to entrench its political dominance through the use of state power and distribution of state resources in exchange for party support to generate control and political power (Butler 2010). While this paper contributes to this argument, on the other hand it provides a different perspective on how the ANC has a dominant grip over its elected incumbents (ANC councillors), which has an impact on their executive autonomy in municipal decision-making.

This paper moves beyond the dominant national discourse on ANC national politics and current President Jacob Zuma's hold onto power as a premise for examining ANC party-state conflation (Southall and Daniel 2009; Southall 2007, 2013; Butler 2009; Booysen 2015). The politics of the ANC and local government state are more complex and vary significantly because of the close proximal location, legitimate political authority and power that the ANC sub-national structures such as the regional executive committee of the ANC have over municipal executives and councillors.

In order to understand the dynamics of municipal decision-making, the paper draws our attention to both the ANC's historical and present context in its party political management practices, which have an impact on the everyday politics of councillor representation in decision-making. Drawing on the 
ANC's principal of democratic centralism, borrowed from the Soviet Union, ${ }^{8}$ it helps to understand why the ANC, post the liberation, continues to operate in a hierarchical and centralised manner when it comes to political decision-making. Although this does not suggest that the ANC operates as a socialist party, it stresses the point that political management ideology borrowed from the Soviet Union continues to find presence in the everyday political management practices and language of the party post the liberation. Within the system of democratic centralism, there is an expectation that political decisions concerning local government made in provincial and regional political structures are binding to ANC councillors and ought to be supported and defended by them without question (Suttner 2009; Southall 2007). In this case, the ANC sees itself as having legitimate political authority over ANC incumbents in state structures.

Within the blurred lines between the ANC party and the state, this paper provides evidence which supports the assertions made by scholars that the ANC regional executive committee attempts to control the agenda of policy decision-making through micro-management of councillors (Lotshwao 2009; Piper and Anciano 2015; Piper and Deacon 2015) and politically appointed municipal bureaucrats (De Visser 2010; Cameron 2010). While ANC regional structures have subordinated municipal structures, such as the municipal mayoral executive committee, into taking collective decisions that show loyalty for the party, this paper argues that loyalty and cooperation comes with a significant degree of resistance and unwillingness, which generate tensions between the "two centres of power" (Reddy 2014) i.e. the ANC regional party structure and the mayoral executive committee. Thus, the influence of the ANC regional party structures does not always guarantee consensus and cooperation from the mayoral executive over council decisions. The case of the Nelson Mandela statue provides us with insight into the tensions and conflicts that arise from this subordination.

\section{Service delivery or Nelson Mandela statue: a case of council decision-making Background of the Nelson Mandela commemoration project}

Upon the passing of Nelson Mandela, the first president of post-apartheid South Africa on $5^{\text {th }}$ December 2013, the provincial executive committee of the ANC in the Northern Cape, which is an elected provincial party in charge of the political management of the ANC in the province, took a decision to erect a statue of Nelson Mandela in one municipality in the province as a part of the ANC national party political mandate of commemorating the ANC anti-apartheid struggle icon. The ANC as a liberation movement has followed an African post-colonial agenda of erecting monuments to celebrate the liberation from colonialism and pay tribute to those who sacrificed their lives in the

\footnotetext{
${ }^{8}$ Stephen Ellis (2012) in his work on The ANC in Exile 1960-1990 during the years of the liberation struggle provides a detailed account of the longstanding relationship between the ANC and the Soviet Union. In his book, we able to trace the historical Marxist-Leninist ideologies such as Democratic Centralism and the National Democratic Revolution, which were adopted by the ANC in its party political language and management practices that were borrowed from the Soviet Union.
} 
struggle (Marschall 2010). ${ }^{9}$ In South Africa, the monument and memorial heritage landscape inherited from apartheid represented an oppressive past that focused on the heritage values of the minority White South Africans under the colonial and apartheid government state."

The erection of post-apartheid monuments ${ }^{10}$ was part of a broader political and social transformation agenda driven by the general understanding that they could be used as "gestures of compensation" (Marschall 2004), which could facilitate a dialogue with the old regime while enabling a process of mourning, confronting the past and nation building. After 1994, there was a general acceptance for the ANC national government to embark on a series of heritage commemoration projects in various municipalities, some funded directly from the government national treasury, and others from provincial and municipal budgets with donations from the private sector. According to Marschall (2010), the ANC saw erecting new monuments as a political opportunity for inscribing new political ideological values and national identity by fostering meaning for the post-apartheid state. Nelson Mandela as an icon of the anti-apartheid struggle became an ideal political symbol for inscribing these socio-political values.

With Nelson Mandela's passing there was national call from the ANC national party for provinces and municipalities to commemorate the legacy of the struggle icon. By the time I embarked on fieldwork in September 2014, the issue of erecting a Nelson Mandela statue was part of the municipality council agenda. In an interview with the mayor, he indicated that the ANC provincial party took a political resolution to initiate such a project in the municipality (interview, 24 October 2014). He also indicated that this project was not part of the developmental projects in the five-year Municipal Integrated Development Plan (IDP) (2011-2016). ${ }^{11}$ Therefore as a project which did not feature in the initial five-year IDP planning and budgeting cycle, the council had to carefully evaluate the costs of the project. An ad-hoc committee ${ }^{12}$ was proposed that would specifically run with the project in order to oversee the project activities (interview, 24 October 2014).

\footnotetext{
${ }^{9}$ For example, the gigantic Ghanaian Independence monument and the Zimbabwe Liberation War Heritage Programme (LZWHP), which established memorial sites like the Heros acre and museums as a way of mourning and paying tribute to those who lost their lives in the liberation struggle.

10 Unlike most post-liberation commemoration projects, South African monuments and memorials were less confrontational, less racially exclusive and less aggressive in terms of visually denouncing colonialism (see Marschall 2010).

${ }^{11}$ Section 23 of the Local Government: Municipal Systems Act 32 of 2000 stipulates that municipalities should develop an Integrated Development Plan which is a policy document that outlines service delivery plans and budget priorities for a five-year cycle. This means that all projects are included at the beginning of this cycle and adjustments are made during an annual review in consultation with communities and ward councillors to determine whether resource allow for new projects to be included.

${ }^{12}$ These committees are given a time frame to oversee certain issues or even projects and should report the progress made to the executive committee and council and later disbanded once the issue is resolved or the project is completed.
} 
The 'Nelson Mandela ad-hoc committee' was already established by the time the fieldwork for this paper was undertaken. Ad-hoc committees are usually established by councils when there is a critical issue which does not fall under a specific portfolio committee. According to the previous mayoral executive committee reports I had read, the Nelson Mandela ad-hoc committee was allocated approximately R500,000 (\$37,000) to conduct a feasibility study on how best to preserve and commemorate the legacy of Nelson Mandela. It was noted in the report that since the municipality did not have the capacity or expertise on heritage issues, the Nelson Mandela ad-committee appointed a consultant to assist the committee with conducting the feasibility study (field notes, municipal council, October 2014).

Out of the R1.7 billion ( $\$ 121$ million) budget of the municipality, an estimated budget of R10 million $(\$ 740,000)$ for the project was presented by the Chief Financial Officer at the IDP Budget Steering Committee. It was proposed that the Nelson Mandela statue should be erected in the local township on an empty space near a motorway intersection, which was demarcated as the Mandela Park. The mayor was not very pleased with this proposal taking into account that it was costly and not budgeted for in the initial five-year IDP cycle, and was concerned that the municipality was struggling to provide essential services on infrastructure projects due to budget constraints. The question the mayor raised during the meeting was:

Why are we allocating so much money [R10 million] (\$740,000) for the Nelson Mandela Monument and yet only R3 million $(\$ 220,000)$ is allocated for surveying of sites? I can also see that there is an amount of R2 million allocated to the mayor's car. Is this car a Maserati? Why do I need to drive such an expensive car? I'm not here for luxuries. We need to prioritise two things: service delivery and selling of land in order to get more revenue for the municipality. Reallocate $R 1.2$ million $(\$ 88,800)$ for my car to land surveying, and get me a decent and affordable car. We need to carefully weigh our priorities and we must prioritise cost saving... By the look of things we will have to get other stakeholders like the Office of the Premier on board to share the costs of this project (mayor, observation of the IDP Budget Steering Committee, October 2014).

At first some of the senior managers chuckled at the mayor's reaction with respect to the amount allocated for his car. Another senior manager mumbled that the mayor 'deserved' a car worth that value because of his long service in the public sector (observation notes, municipality, 29 October 2014). The failure to recognise his sarcastic disapproval of the finance department's rationale in allocating funds he thought were excessive annoyed the mayor, who emphasised that "we cannot be wasting municipal resources on activities that were not adding value to the primary objectives of local government" (observation notes, mayor, 29 October 2014). The mayor's concerns illustrate that mayors appointed as political leaders constantly have to critically question administrative advice on resource distribution and expenditure. His emphasis on service delivery and prioritisation highlights how municipal executive decision-makers are constantly faced with trade-offs when making decisions. Moreover, it shows how the mayor was being cautious about excessive spending of municipal resources on what he views as less important 'luxuries', which could be symbolically 
interpreted as using state resources for self-indulgence and private gain which could be potentially problematic in the eyes of the electorate.

The issue of excessive spending by elected and appointed government officials of government resources for private gain was under serious public scrutiny during 2013 to 2015 as a result of the perceived excessive spending on security for President Jacob Zuma's private home in Nkandla, revealed by the Public Protector (2014). ${ }^{13}$ This issue coincided with the fieldwork, and was a hot topical issue amongst ANC councillors during the informal discussions for this project. ANC councillors often used the 'Nkandla' issue to illustrate how ANC politicians and state authorities were recklessly using state resources without prioritising the needs of citizens (field notes, municipal council, October 2014 - November 2014).

The public discourse around the conduct of ANC officials ignited by the Nkandla report seems to have created an awareness amongst ANC politicians of the need to be more careful about public spending and to question the work of bureaucrats who misguide politicians. The mayor was thus making it an explicit responsibility to be more cautious about public spending and channelling resources towards improving the delivery of services to communities.

\section{Internal opposition and divided views amongst ANC councillors}

In November 2014, the mayor delivered his first quarter budget report, which included the budget allocation for the project. The ad-hoc committee also presented a verbal update report to council. The committee was advised that a full written report should be taken to council, to include discussion of the current conditions of existing monuments and heritage sites, so that the project would be linked with the municipality's heritage landscape. ANC councillors, particularly the chairperson of the Municipal Public Accounts Committee (MPAC) - a committee that scrutinises the finances of the municipality - cautioned the committee that it should carefully monitor the financial spending on the proposal which should be within the budget. This view was also echoed by a DA councillor (observation notes, municipal council, 2 November 2014).

After the council meeting, a short focus group discussion was held with six ANC ward councillors who were not on the Nelson Mandela ad-hoc committee to get their views on the proposed project, seeing that municipal finances seemed to have taken centre stage in the deliberations. They indicated that this project was hotly debated in the ANC party caucus ${ }^{14}$ before the council meeting. Although

\footnotetext{
${ }^{13}$ See Public Prosecutor Report on 'Secure in Comfort'. Available at: www.pprotect.org/library/investigation_report/2013-14/Final\%20Report\%2019\%20March\%202014\%20.pdf

14 The ANC Party Caucus is a group of councillors headed by the ANC chief whip to debate council agenda and agree on the ANC party position on issues that ought to be represented by ANC councillors in council. Therefore the ANC caucus and whip system facilitates a system of internal party democracy on council matters, ensuring the passage through which ANC regional and branch party decisions are cascaded down to the mayoral executive committee by means of debate and consensus through majority and popular vote.
} 
ANC councillors understood and appreciated the political significance of the project, they raised concerns about the municipality spending money on activities they considered less to do with service delivery (focus group discussion, ANC ward councillors, 2 November 2014). One of the councillors who is a member of the Municipal Public Accounts Committee, expressed this view:

We are not saying that we should not honour Mandela. But as a man who stood for moral values and principles, Mandela would not want government resources to be wasted on activities which do not benefit the community. Councillors are flying business class to Eastern Cape and Cape Town, staying in expensive hotels and getting big allowances, but meanwhile the municipality is in a financial crisis and our wards are suffering. Councillors are supposed to play an oversight role, but they are not doing that - they just accept things without questioning them. Other councillors will not ask questions because they are benefiting and enjoying the privileges that come with the project (focus group discussion, councillor, 2 November 2014).

Another councillor added that:

You should visit our wards. You will see...there are potholes everywhere. Municipal water pipes are constantly bursting because they old. But we are told there isn't enough money to replace these pipes and upgrade our infrastructure. But the ANC leadership wants us to approve this project instead putting this money on service delivery priorities. How do we justify this to our communities? (focus group discussion, 2 November 2014).

Thus, though the small focus group of ANC councillors did not overtly object to the project in council, they did not fully support the ANC caucus collective decision to proceed with the project. When asked why the councillors did not raise concerns in council, they said that as an ANC party group, they have to 'collectively' support decisions of the ANC party. Thus although the ANC party aimed to present a unanimous voice by endorsing the project in council, the reality behind the scenes was different (Copus 2004). There was a general consensus in the small focus group of ANC ward councillors that they held strong opposing views and questioned the political rationale behind the project under the prevailing financial constraints. They also indicated that their argument for prioritising service delivery was not strongly supported by members of the Nelson Mandela ad-hoc committee.

Ironically, commentators such as Mashele and Qobo (2014) and Ndletyana (2015) suggest that ANC officials have lost their moral compass. However, in this case some ANC ward councillors placed emphasis on political accountability, and a moral economic argument based on the principles that Nelson Mandela stood for as leader. Spending money on commemorating a leader of high moral standing contextualised ANC councillors' political judgement in this decision-making processes. Moreover, ward councillors were beginning to draw the link between the council decisions with expected service delivery outcomes for their constituencies (Pressman and Wildavsky 1978), which also has an implication on accountability of councillors to their communities for ward service delivery. However, while councillors may have had the interests of their communities at heart, the process of collective group decision-making may have constrained councillors from fulfilling their 
primary role as community representatives. This resonates with Copus' (2004) argument on how representative democracy often yields tensions, especially where the dual representational roles of being a party agent and people's agent (Newton 1974; Corina 1974) come into conflict as result of competing interests.

\section{Negotiating with ANC party structure behind the scenes}

The R10 million $(\$ 740,000)$ allocated to the project delivered by the mayor in his budget speech also gained negative local media attention. ${ }^{15}$ Councillors from the opposition party made media statements in the local newspaper, expressing their concerns with the project and questioning the council's priorities on resource allocation. They complained about deteriorating infrastructure while the municipality was prepared to spend R10 million $(\$ 740,000)$ on a 'monument' (Daily Mail newspaper, 2 March 2015). ${ }^{16}$ As a result, the mayor decided to develop a plan to contain the situation and prevent it from erupting into political leverage for the opposition party.

The mayor indicated that he had raised his concerns with the ANC regional party officials around the 'negative publicity' the statue project was generating in the media and amongst the opposition parties and his members of the ANC party in council (informal discussion, 15 March 2015). He communicated his suggestion to abandon the project. However, this suggestion did not receive much support from ANC regional party officials, including the ANC council chief whip, whom according to the mayor, insisted that the project should continue and be financed by the municipality. The mayor indicated that he decided to escalate the matter to the ANC provincial party officials and held private one-to-one talks to persuade them to put the project on hold until after the 2016 local government elections. The mayor insisted that:

The matter is really spiralling out of control due to the negative media statements which are attracting unnecessary attention for the ANC. The opposition party is using this as a campaign strategy against the ANC before the 2016 local government elections. I'm worried because this municipality is struggling with its finances and this will make us look bad to our supporters (informal discussion, mayor, 15 March 2015).

\footnotetext{
15 As an ethnographer, my link to the mayor was known, and other organisational actors realised that he would be the key informant on politically sensitive matters relating to the municipality. Therefore protecting the identity of the mayor from other institutional actors naturally proved to be difficult. On the other hand I decided to let all participants (including the mayor) know that the findings of my research would not be shared with anyone in the municipality before the 2016 local government elections. I had to emphasise to my participants that the purpose of my research was not to expose corruption and bad conduct of ANC councillors and administrators, but rather to study how the institution works by reflecting on both its weaknesses and strengths, as well as practices, as these could assist in understanding how councillors respond and deal with challenges in municipal decision-making. I also adhered to ethical codes of conduct by keeping my informant anonymous, and treated information with confidentiality in order to maintain the trust I had earned from my informants. The mayor and key informants have seen a full draft of this work and approved it for publication.

16 For the purpose of protecting the identity of the municipality and participants, I have used a pseudonym for the newspaper because the headlines of newspaper article on the statue contains the actual name of the town where the municipality is situated.
} 
When asked why he decide to bypass the ANC regional party and directly talk to ANC provincial party officials, the mayor indicated that he had encountered resistance to renegotiating the project from the ANC regional party. There were also suspicions that ANC regional officials may have had personal interests in the project. The ANC provincial officials agreed to his proposal to put the project on hold.

The mayor further persuaded the ANC provincial party officials to allow for long-term joint discussions between the municipality and provincial departments such as the Department of Arts and Culture and Office of the Premier, to assist in drawing up a business model for sharing the financial costs of the project after the 2016 local government elections. The aim was to structure the project as a development project that addressed the infrastructure developmental needs of the municipality, rather than just building a monument (informal discussion, 15 March 2015). This proposal was taken to the mayoral executive committee which then recommended to council to put the project on hold citing 'resource constraints' and explore other alternative models for project development.

The political decision-making dynamics between the ANC region and provincial officials illustrate the hierarchal manner in which ANC decision-making processes are structured and the reciprocal and fluid approach to influencing party decisions. This reflects the ANC's democratic centralist approach, which gives top-political structures the authority to make final decisions on matters concerning the party at local government level (Southall 2007). However, although the ANC provincial party structure sees itself as the highest decision-making body in the province above the regional structure, the mayor's ability to sway the ANC provincial party's 'political mandate' decision to reconsider the project in his municipality demonstrated that the influence between the party and mayor was a twoway reciprocal process. This involved negotiations behind the scenes, outside the formal municipality executive decision-making spaces.

The mayor's direct access and connection to the ANC provincial party officials was a result of his close personal relations with ANC rank-and-file provincial government politicians. He also had a long political service as a former member of the ANC provincial executive committee, political head in the Provincial Ministry of Health and the ANC chief whip in the provincial legislature, before assuming political office in the municipality, which gave him the leverage to lobby key provincial government politicians. This leverage at provincial level was of little importance at ANC regional level, where his attempt to persuade the ANC regional party officials to cancel the project in the municipality failed. The mayor was not an elected member of the ANC regional party, which sees itself as a political authority over municipal decisions, which means that the mayor may have been seen as a subordinate rather than a senior party member, who should accept ANC regional party decisions irrespective of his former position in the provincial party and his current powers an executive mayor. 
Reddy's work on liberation parties draws on degenerative factionalism to explain how it has become characteristic for liberation movements in power to experience tensions and factionalism between "two centres of power" (2014, p. 221), referring to the ANC party structure and the ANC party members appointed to serve in government. ${ }^{17}$ Reddy explains how "party members serving in government" feel hampered by the constant interference of ANC party structures outside of government, while the ANC party structures outside government may also feel undermined by party members serving in government who are not responsive to decisions of ANC party structures (Reddy 2014, p. 221).

However, evidence presented in this paper on the intra-political dynamics between ANC regional party structures and the mayor suggests that it would be too simplistic to use 'degenerative factionalism' theory to explain the lack of political accountability of state actors. Rather, the political differences between party political interests at regional level vs municipal service delivery needs highlighted by the mayor illuminate the conflict between 'two centres of power' and struggles to gain control over municipal decision-making, influenced by the objective of some parties to distribute state resources for private gain as illustrated in the next section.

\section{Hidden financial misconduct}

The purpose of this study was not to expose a specific instance of local government financial misconduct or corruption. Rather the aim was to explore through observation the actions and practices of a set of local government politicians within their institutional setting. It cannot be ignored that as an ethnographer, one would encounter sensitive issues which may not easily be visible and accessible to outsiders due to the closeness of the researcher with the participants under study. Therefore consistent reflection became necessary at all times on my role as a researcher and the impact it would have on my participants upon the discovery of such grey areas. Nevertheless, it is important that any practices that could be considered questionable should be explored in order to analyse the reasons for such actions and understand how politicians deal with financial misconduct.

After the mayoral executive committee's recommendation to put the project on hold, there was an unusual turn of events. One afternoon, on the $12^{\text {th }}$ of April 2015, a month after the budget speech, the mayor called me to his office to talk about the discovery he had made concerning the project. Apparently, the mayor in his private engagements with one of the ANC provincial party members indicated that the real project value was $\mathrm{R} 72$ million $(\$ 5,300,000)$, of which the mayor and executive committee were not aware.

\footnotetext{
${ }^{17}$ In Reddy's (2014) work, he demonstrates how factionalism emerges from within the party due to competing "centres of power" generated by internal competition for access to state power and resources which mutate to degenerative factions. The degenerative factions analytical framework has been predominantly applied to ANC national political dynamics which emerged post the Polokwane Conference, where the ANC was divided into two dominant factions (Jacob Zuma vs Thabo Mbeki), ANC state political bureaucrats vs ANC party officials.
} 
The mayor expressed the following comments:

Apparently, a reliable comrade in the provincial leadership revealed to me that the project was allegedly going to cost us $R 72$ million $(\$ 5,300,000)$ instead of the $R 10$ million $(\$ 740,000)$. It seems that the project is being pushed by certain individuals in our political ranks in the ANC regional party who want to benefit from it. I also discovered that huge amounts of monies had already been paid to the service provider. I am writing a letter to the municipal manager to conduct an internal investigation. I don't want my name to be dragged in things which will put me behind bars. Like I said, we cannot afford to spend so much, meanwhile we cannot afford to upgrade our service delivery infrastructure. We need to focus on infrastructure development as we prepare for the elections (mayor, informal discussion, 13 April, 2015).

This response first indicates that there was lack of transparency and some form of financial misconduct committed in relation to the project. ${ }^{18}$ However, this misconduct had been hidden from scrutiny by the administration from the mayor and his executive committee. Second, the response suggests that ANC regional party officials operating outside the municipal mayoral executive structure could use their political power and authority to influence the administration to irregularly distribute state resources. As noted by Olivier de Sardan (1999) such actions are difficult to pinpoint because of the discrete nature of interaction between state officials and ANC regional party officials. One can only confirm such actions through the media, with authorities, local talks and conversations with councillors (see Blundo 2007). As an ethnographic researcher, I have been able to develop a close relationship with my participants over the months. Ethnographers should build a good rapport with their informants (Agar 1996), who can eventually talk openly. ${ }^{19}$ In this case, the role of the researcher can mutate into providing reassurance, if not an opportunity for participants to vent their frustrations and negative experiences.

\section{Formal and informal processes of dealing with financial misconduct}

Against the backdrop of the mayor's request to the municipal manager to conduct an investigation, the aim of the ANC provincial officials was to ensure that a political solution was found in order to prevent the situation from erupting into an unpleasant 'political crisis', which could dent the image of the ANC in the run up to the local government elections (informal discussion, 2 December 2015). The mayor who is in charge of the municipal budget and institutional governance, has a legal obligation to conduct investigations and report on the findings to the mayoral executive committee and to council in order for council to take disciplinary action against those implicated in financial misconduct (South African Local Government Municipal Finance Management Act 2003). Although the mayor did not disclose in full details of decisions taken by the ANC provincial party officials, the report was not

\footnotetext{
${ }^{18}$ Section 171 (1a-d) of the Local Government: Municipal Finance Management Act 53 of 2003 states that if officials should be found to have instructed an official to make an unauthorised transaction and provided misleading information to the mayor or council, this should be regarded as financial misconduct and disciplinary steps should be taken.

${ }^{19}$ Argar (1996, p. 138) provides several examples such as respect for other opinions, being a good listener, and adapting into group life by taking an interest in the experiences of informants, which encourages them to feel the need to talk to the researcher willingly.
} 
brought to the mayoral executive committee or council meetings between October 2014 to August 2015 , the time at which the fieldwork was carried out.

The year 2015 was a critical campaigning period for the 2016 local government elections; the mayor's preoccupation with the elections and decision to involve the ANC provincial party officials indicates how decision-making can be influenced by both informal party political interests and formal administrative legal-rational. Although the mayor had expressed his disapproval of the financial misconduct, nonetheless this did not guarantee legal sanctions against the officials in the finance department bearing in mind that there were political implications considered important by the mayor. Towards the last month of fieldwork in July 2015, the mayor indicated that according to the municipal manager's investigation outcome, it had been confirmed that there were indeed financial irregularities that were committed by the finance department and the report was handed over to the state legal authority (known as HAWKS) to officially open up an investigation into corruption (informal discussion, mayor, 21 July 2015).

Due to the magnitude of the financial misconduct, the mayor indicated that he had no alternative but to hand over the case to the law enforcement agency for further investigation. He indicated that he also had written a statement giving his side of the story on what had initially happened concerning the financial affairs of the project in order to provide clarity on his role around the issue (informal discussion, mayor, 21 July 2015). There was no clear indication as what had happened to the HAWKS investigation. The ambiguous way in which the mayor dealt with this matter shows how political and bureaucratic norms and rules are applied simultaneously in the choices made by politicians in dealing with financial misconduct and deviations. For the mayor, it was both about protecting his personal integrity while also ensuring that his ANC party was protected from public exposure. As to whether the aim of the investigation was to initiate legal sanctions against the alleged officials involved remains doubtful as the matter was never formerly brought to the mayoral executive committee and council. Therefore it is difficult to disentangle the rationale and reasons for using both informal and formal channels of dealing with alleged municipal corruption. On the other hand, opting for the ANC party involved demonstrates the mayor's dependency on the ANC's political approval in dealing with state related matters, which constrains him from using his legislative executive powers and authority as the political head of the municipality.

\section{Patchwork of ethics, ANC party loyalty and bureaucratic rules}

Before completing fieldwork, I had another follow-up discussion with the Municipal Public Accounts Committee chairperson, with the intention of obtaining more information about how the MPAC and ANC as the ruling party in council, handled incidences of alleged corruption and administration deviations. 
He provided this insightful example of the dilemma faced by ANC councillors when having to deal with administrative financial misconduct:

Sometimes it is difficult to do these investigations because of political interference. At the end of the day this is our party [referring to the ANC]... We are caught in-between the rock and a hard place. Because of the interests of the party, you can't dig too much because you will expose certain things that will dent the image of the party and fellow ANC comrades. The only thing you can do is to make the system work better now, putting in control systems in place in order to prevent [future] corruption (interview with MPAC chairperson, councillor, 17 August 2015).

This gives an example of the ways in which party loyalty from ANC councillors is entrenched at the expense of applying legal sanctions and bureaucratic rules against the deviant behaviour of serving ANC party members. This shows how handling state official misconduct through a political process may allow impunity and may prohibit the elected officials from holding those implicated accountable, which does not accord with the Weberian bureaucratic legal-rational system. It has been common practice in the ANC where public service bureaucrats who transgress the public service code of conduct are rarely subjected to disciplinary measures. ${ }^{20}$ This can also be traced to the historic political culture of impunity and tendency to resolve internal problems through internal political processes (see Mashele and Qobo 2014; Johnson 2015).

'Corruption' does not occur in a vacuum (Chabal and Daloz 1999, p. 77), but is embedded in amongst other mechanisms such as the political culture, patron-client relations, general exchange for political favours, a culture of impunity and the day-to-day routine of the administration that become very difficult to distinguish between corrupted practices and everyday informal practices (Olivier de Sardan 1999, 2014). This relates strongly to the issue that was raised by ANC ward councillors in a focus group discussion, where they indicated that one of the main problems which constrained councillors from taking legal action against municipal senior managers and administration was that they enjoyed 'political protection' from ANC politicians (focus group discussion, ANC ward councillors, March 2015). Thus local government managers and administrators associated with the ANC party appear to function within a system of impunity reinforced by the ANC partisan administration system of patron-client relations between ANC provincial and regional party officials and ANC bureaucrats.

When asked about what ethical implications this had on councillors, particularly on the MPAC chairperson's role as the chair of a portfolio committee responsible for promoting accountability, and ethical conduct of elected and appointed officials, the official provided another example of his own

\footnotetext{
${ }^{20}$ The ANC recently established a party integrity commission in response to the escalation of concern over unethical conduct of some party members. However, the ANC Secretary General, Gwede Mantashe (2015) said that party structures needed to understand that the integrity commission was not a disciplinary committee, in which the principle of innocent until proven guilty applied ought to be adhered to (http://mg.co.za/article/2015-05-28-the-anc-is-ignoring-its-own-moral-police). [Accessed June 2015].
} 
personal experience, where he found it difficult to act alone if he did not have the support of other

ANC councillors:

For example, there was a tender awarded to a company that did not have tax clearance some time ago. The law says you cannot award a tender to a company that does not have a tax clearance. But these administrative officials awarded this tender but they are still working in our municipality. No action was taken by the municipality or the party [ANC]. I as the MPAC chairperson cannot take action alone. I need my ANC committee members to support whatever recommendation I make. If I don't get the support, then nothing will happen. That's why I stood up in a council meeting after delivering our MPAC report and emphasised that these officials must be named and shamed, so they can face consequences for their actions and be barred for participating in tender processes in the future. But that did not happen because the party [ANC] wouldn't allow it to happen (MPAC chairperson, 17 August 2015).

He further went to state that:

When it comes to the debate about one's ethical position, it's a difficult one. I must confess, I for one am a little bit lenient when it comes to the party [ANC]. I remember we once conducted an investigation about monies which were paid out for disaster management relief. Our investigation led us to find out that these monies were paid out to ANC branch volunteers. When we told the party leadership [ANC regional party] about the findings, we were told not to pursue the matter because it would cause problems for the party [ANC]. So we closed down the report. But there is a limit.... if it's an individual party [ANC] member attempting to enrich themselves, I have a serious problem and I won't cooperate (interview with MPAC chairperson, 17 August 2015).

This reflection provides a striking insight into another form of representational dilemma of ANC councillors serving as chairpersons of portfolio committees. The dilemma here is an ethical one as well as a political one - choosing between protecting the interests of the ANC party or the state when they have to take a position on how to deal with financial misconduct and allegations of corruption committed by fellow ANC party members who are 'deployed' as senior managers or elected as councillors. Firstly, this elucidates that ANC councillors do think about the personal ethical conflict which comes with the role of representing the state and ANC party political interests. However, there is fluidity and selectiveness in applying the law, where investigation reports are swept under the carpet because of the political implications it might have for the ANC party and partisan officials involved. Secondly, the personal ethical conflict also comes into play when ANC councillors willingly protect ANC party members and officials implicated in unethical and deviant behaviour. The willingness of concealing investigation reports is used as mechanism of showing loyalty.

Thirdly, the interplay of personal ethical principles and general party interests in applying the law comes in when it also involves beneficiaries of state resources. In other words, the distribution of state resources to a critical mass of ANC members is viewed by the MPAC chairperson as more justifiable because according to him, it does not equate to self-enrichment of a few individual ANC members. However, private gain and mass accumulation of wealth by a few ANC party members using state resources may be strongly condemned by ANC councillors. This demonstrates inconsistencies in 
dealing with corruption by ANC councillors, in what Anders (2014, pp. 135-9) termed as a "patchwork of morality" in his study on governance reform in Malawi. Thus dealing with corruption is carefully negotiated and interwoven with personal and political moral justification in decisionmaking rather than a simple process applying legal processes (Therkildsen 2014, p. 124).

It has been argued by Butler (2015) and Beresford (2014) that this blurred approach between the ANC party and the state processes in dealing with governance issues has a danger of undermining the autonomy of formal state processes when dealing with corruption. It also deters state actors from exercising their representational duty and role of holding those implicated in misconduct to account for their actions. Finding a balance between both in decision-making is highly valued by some political office-bearers and applied sporadically and selectively by others.

Although there are formal institutional rules that govern institutional actors, designed to curb unwanted practices and promote public service ethics amongst politicians and bureaucrats, institutional rules depend on the actions of actors who give meaning to institutions. Lowndes and Leach (2004, pp. 561-563) state that, "local political institutions are embedded in a wider political environment and within a specific local context. This gives the notion that both formal and informal dimensions of state institutions create a complex interaction between both dimensions". The formal procedures for dealing with allegations of financial misconduct in the local government legislation and informal ANC political process marks the tacit tensions between prescribed roles and responsibilities of councillors and the practical norms they apply in reality.

\section{Conclusion}

This paper has provided a detailed insight through account and observation of the everyday practices and complexities of council decision-making. Through the experience of the mayor and other ANC councillors and their relationship with ANC party structures, the paper also demonstrates the complexities of the dominance of ANC political management and the interface between the ANC provincial and regional party. Whilst ANC councillors and political office-bearers such as the mayor understand that their primary focus should be channelled towards representing the service delivery interests of their communities, the partisan role of ANC councillors often conflicts with popular citizen interests. The concern of the Nelson Mandela statue being viewed as a 'wasteful expenditure' by the mayor and other ANC ward councillors while the ANC regional party viewed it as a political priority demonstrates the tensions of councillor representation that may arise in local government decision-making. It also accentuates how councillors have to be cautious about allocating state resources for activities that would be viewed as non-beneficial in terms of providing basic public goods and services to the community. 
Although statues and memorials have been seen as icons in the post-apartheid political agenda of the ANC, ANC councillors have become more sceptical about approving the allocation of resources which are seen as unjustifiable to communities. On the other hand this paper has been able to show the limitations of mayoral decision-making powers and functions, which are constrained by the dominant presence of ANC regional party structures, which wield authority and power over ANC councillors in municipal decision-making. Irrespective of the mayor's executive powers, the mayor has to be a broker between the municipal organisation and the different levels of ANC party structures, using the media, opposition party and popular dissenting views of ANC councillors as tools in the negotiation. Therefore ANC political mandates and community interests are politically negotiated between decision-makers such as the mayor and his superiors in the ANC provincial structure.

This paper has also demonstrated how large projects may also place decision-makers in a precarious position, because they can foster an opportunity for financial private gain for municipal officials and ANC regional officials. Despite a general perception that councillors are often entangled in municipal corruption, senior administrative and financial managers for the municipality are in fact more directly involved in the manipulation of municipal finances as facilitators for ANC regional officials as possible beneficiaries. The mayor's choice of dealing with allegations of financial misconduct is influenced by the interplay of both informal and formal political and administrative norms and processes that are also shaped by his own personal norms and values.

Political pressure to show loyalty to the ANC party experienced by the mayor and other ANC councillors forced political office holders to ignore legal recourse against those implicated in financial misconduct. In summary, the case of the Nelson Mandela statue has shown the need to understand that local municipalities are embedded within both internal organisational and external ANC party dynamics as sites of contestation. We have seen how prescribed legislative rules that define the lines of power and authority are contradicted by overlapping political party power structures seeking to capture power and authority in decision-making. It is within these complexities and contradictions that we need to understand the politics of council decision-making and councillor representation.

\section{References}

Agar, M.H. (1996) Speaking of ethnography. Beverly Hills CA: Sage.

Alexander, P. (2010) Rebellion of the poor: South Africa's service delivery protests - a preliminary analysis. Review of African Political Economy, 37 (123), 25-40. doi: https://doi.org/10.1080/03056241003637870

Anders, G. (2014) Old-school bureaucrats and technocrats in Malawi: Civil service reform in practice. In: Bierschenk, T. and Oliver de Sardan, J.P. (eds) States at work: Dynamics of African bureaucracies (pp. 329-348). Leiden: Brill. doi: https://doi.org/10.1163/9789004264960_014

Atkinson, D. (2007) Taking to the streets: Has developmental local government failed in South Africa. In: Buhlungu, S., Daniel, J., Southall, R. and Lutchmann, J. (eds) State of the nation South Africa (pp. 5377). Cape Town: HSRC Press. 
Babbie, E. and Mouton, J. (2001) The practice of social research. South Africa: Oxford University Press.

Ballard, R.; Habib, A. and Valodia, I. (2006) Voices of protest: Social movements in post-apartheid South Africa. Pietermaritzburg: UKZN Press.

Beresford, A. (2014) Power, patronage and gatekeeper politics in South Africa. African Studies, 114 (455), 226248.

Blundo, G. (2007) Hidden acts, open talks. How anthropology can 'observe' and describe corruption. In: Anders, G. and Nuijten, M. (eds) Corruption and the secret of law: A legal anthropological perspective (law, justice and power) (pp. 122-145). Aldershot, England: Ashgate Publishing.

Bompani, B. (2006) Mandela mania: Mainline churches in post-apartheid South Africa. Third World Quarterly, 27 (6), 1137-1149. doi: https://doi.org/10.1080/01436590600842449

Booysen, S. (2015) Dominance and decline: The ANC in the time of Zuma. Johannesburg: Wits University Press.

Brewer, J.D. (2004) Ethnography. In: Cassell, C. and Symon, G. (eds) Essential guide to qualitative methods in organizational research (pp. 312-322). London: Sage. doi: https://doi.org/10.4135/9781446280119.n25

Burawoy, M. (2003) An outline of a theory of reflexive ethnography. American Sociological Review, 68 (5), 645-679. doi: https://doi.org/10.2307/1519757

Butler, A. (2009) Considering on the erosion of one-party dominance. Representation: Journal of Representative Democracy, 45 (2), 159-172. doi: https://doi.org/10.1080/00344890902945681

Butler, A. (2010) Consolidation first: Institutional reform priorities in the creation of a developmental state in South Africa. In: Edigheji, O. (ed) Constructing a developmental state in South Africa: Potentials and challenges. Cape Town: HSRC Press.

Butler, A. (2015) The politics of numbers: National membership growth and sub-national power competition in the ANC. Transformation: Critical Perspectives on Southern Africa, 87, 13-31. doi: https://doi.org/10.1353/trn.2015.0008

Butler, A. and Southall, R. (2015) Understanding the ANC at sub-national level. Transformation: Critical Perspectives on Southern Africa, 87, 1-12. doi: https://doi.org/10.1353/trn.2015.0006

Cameron, R. (2010) Redefining political-administrative relationships in South Africa. Paper presented at the $14^{\text {th }}$ IRSPM Conference in Berne Switzerland 6-9 April 2010. doi: https://doi.org/10.1177/0020852310381204

Chabal, P. and Daloz, J. (1999) Africa works: Disorder as political instrument. Oxford: James Currey.

Copus, C. (2004) Party politics and local government. Manchester: Manchester University Press.

Corina, L. (1974) Elected representatives in a party system: A typology. Policy and Politics, 3 (1), 69-87. doi: https://doi.org/10.1332/030557375783094743

Dahl, R. (1956) A preface to democratic theory. Chicago: University of Chicago Press.

Dawson, H.J. (2014) Patronage from below: Political unrest in an informal settlement in South Africa. African Affairs, 113 (453), 518-39. doi: https://doi.org/10.1093/afraf/adu056

De Visser, J. (2010) Political-administration interface in South African municipalities Assessing the quality of local democracy. Commonwealth Journal of Local Governance, 5, 86-101.

Dearlove, J. (1973) The politics of policy in local government. Cambridge: Cambridge University Press.

Department of Cooperative Government and Traditional Affairs. (2009) The state of local government in South Africa: An overview report. Pretoria: Department of Cooperative Government and Traditional Affairs.

Dorman, S. (2006) Post-liberation politics in Africa: Examining the political legacy of struggle. Third World Quarterly, 27 (6), 1085-1101. doi: https://doi.org/10.1080/01436590600842365

Ellis, S. (2012) External missions: The ANC in exile. Johannesburg: Jonathan Ball Publishers.

Eulau, H. (1978) Changing views of representation. In: Eulau, H. and Wahlke, J.C. (eds) The politics of representation continuities in theory and research (pp. 31-53). London: Sage.

Fine, B. (2010) Can South Africa be a developmental state? In: Edigheji, O. (ed) Constructing a developmental state in South Africa: Potentials and challenges (pp. 275-291). Cape Town: HSRC Press. 
Fung, A. and Wright, E. (2001) Deepening democracy: Innovations in empowered participatory governance. Politics and Society, 29 (1), 5-41. doi: https://doi.org/10.1177/0032329201029001002

Giliomee, H. and Simkins, C. (1999) The awkward embrace: One party domination and democracy in industrialising countries. London: Routledge.

Heclo, H.H. (1969) The councillor's job. Public Administration, 47 (2), 185-202. doi: https://doi.org/10.1111/j.1467-9299.1969.tb01146.x

Hyslop, J. (2005) Political corruption before and after apartheid. Journal of Southern African Studies, 31 (4), 773-89. doi: https://doi.org/10.1080/03057070500370555

Independent Electoral Commission. (2016) Municipal elections outcome. Available at: http://www.elections.org.za/content/Elections/Municipal-elections-results/. [Accessed August 2016].

Johnson, R.W. (2015) How long will South Africa survive? London: Hurst and Company.

Lasswell, H. (1956) The decision process: Seven categories of functional analysis. College Park: Bureau of Governmental Research, University of Maryland Press.

Lindblom, C.E. (1959) The science of muddling through. Public Administration Review, 19 (2), 79-88. doi: https://doi.org/10.2307/973677

Local Government: Municipal Systems Act 2000 (Act 32 of 2000). Cape Town: Government of the Republic of South Africa.

Local Government: Municipal Finance Management 2003 (Act 56 of 2003). Cape Town: Government of the Republic of South Africa.

Lodge, T. (1998) Political corruption in South Africa. African Affairs, 97 (387), 157-87. doi: https://doi.org/10.1093/oxfordjournals.afraf.a007924

Lodge, T. (2014) Neo-patrimonial politics in the ANC. African Affairs, 113 (450), 1-24. doi: https://doi.org/10.1093/afraf/adt069v

Lotshwao, K. (2009) The lack of internal party democracy in the African National Congress: A threat to the consolidation of democracy in South Africa. Journal of Southern African Studies, 35 (4), 901-914. doi: https://doi.org/10.1080/03057070903313244

Lowndes, V. and Leach, S. (2004) Understanding local political leadership: Constitutions, contexts and capabilities. Local Government Studies, 30 (4), 557- 575. doi: https://doi.org/10.1080/0300393042000333863

Marschall, S. (2004) Gestures of compensation: Post-apartheid monuments and memorials. Transformation: Critical Perspectives on Southern Africa, 55 (1), 78-95. doi: https://doi.org/10.1353/trn.2005.0009

Marschall, S. (2010) Landscape of memory. Commemorative monuments, memorials and public statuary in post-apartheid South Africa. Available at: https://www.researchgate.net/publication [Accessed 17 January 2016].

Mashele, P. and Qobo, M. (2014) The fall of the ANC: What next? Picador Africa, Johannesburg.

Mill, J.S. (1865) Considerations on representative government. London: Longman.

Ndletyana, M. (2015) ANC: From an emancipatory to a rent-seeking instrument. Transformation: Critical Perspectives on Southern Africa, 87, 95-116. doi: https://doi.org/10.1353/trn.2015.0003

Ndletyana, M., Makhalemele, P.O. and Mathekga, R. (2014) Patronage politics divides us: A study on poverty patronage and inequality in South Africa. Pretoria: Mapungubwe Institute Publication.

Newton, K. (1974) Role orientations and their sources among elected representatives in English local politics. Journal of Politics, 36 (3), 615-636. doi: https://doi.org/10.2307/2129247

Oliver, T. (2011) Representation in the appointed state: The case of councillors in the West Midlands Regional Assembly. Unpublished PhD Thesis. University of Birmingham.

Olivier de Sardan, J.P. (1999) A moral economy of corruption in Africa? Journal of Modern African Studies, 37 (1), 25-52. doi: https://doi.org/10.1017/S0022278X99002992 
Olivier de Sardan, J.P. (2014) Interface bureaucrats, professional cultures and the bureaucratic mode of governance. In Bierschenk, T. and Olivier de Sardan, J.P. (eds) States at work: Dynamics of African bureaucracies (pp. 399-429). Brill, Leiden. doi: https://doi.org/10.1163/9789004264960_017

Parsons, W. (1995) Public policy: An introduction to the theory and practice of policy analysis. London: Edward Elgar Publishers.

Pernegger, L. (2015) The antagonistic state: Metropolitan government responses to city strife post-1994. In: Haferburg, C. and Huchzermeyer, M. (eds) Urban governance in post-apartheid (pp. 61-78). Pietermaritzburg: UKZN Press.

Pieterse, E. and Van Donk, M. (2013) Local government and poverty reduction. In: Pillay, U., Hagg, G. and Nyamnjoh, R. (eds) State of the nation South Africa 2012-2013. Cape Town. HSRC Press.

Piper, L. and Anciano, F. (2015) Party over outsiders, centre over branches: How ANC domination works at community level in South Africa. Transformation: Critical Perspectives on Southern Africa, 87, 72-94. doi: https://doi.org/10.1353/trn.2015.0001

Piper, L. and Deacon, R. (2015) Party politics, elite accountability and public participation: Ward committee politics in the Msunduzi municipality. Transformation: Critical Perspectives on Southern Africa, 87, 7294. doi: https://doi.org/10.1353/trn.2015.0001

Pithouse, R. (2015) Undergoing the silence of the present: The imperative to recognise the shack settlement as a site of politics. In: Harferburg, C. and Huchzermeyer, M. (eds) Urban governance in post apartheid cities (pp. 135-154). Pietermaritzburg: UKZN Press.

Pitkin, H.F. (1967) The concept of representation. Berkeley: University of California Press.

Pressman, J.L. and Wildavsky, L. (1978) Implementation. Berkley: University of California.

Reddy, T. (2014) Factional dynamics in Indian National Congress and the African National Congress. In: Butler, A. (ed) Remaking the ANC: Party change in South Africa and the global South. South Africa: Jacana Publishers.

Ritchies, J and Lewis, J. (2003) Qualitative research practice: A guide for social science students. London: Sage Publications.

Rhodes, R.A.W. (2007) The everyday life of a minister. In: Rhodes, R.A.W., 't Hart, P. and Noordegraaf, M. (eds) Observing government elites (pp. 76-98). London: Palgrave. doi: https://doi.org/10.1057/9780230592360_2 and https://doi.org/10.1057/9780230592360

Rhodes, R.A.W., 't Hart, P. and Noordegraaf, M. (2007) Being there. In: Rhodes, R.A.W., 't Hart, P. and Noordegraaf, M. (eds) Observing government elites (pp. 1-17). London: Palgrave. doi: https://doi.org/10.1057/9780230592360_1 and https://doi.org/10.1057/9780230592360

Schulz-Herzenberg, C. (2007) A silent revolution: South African voters, 1994-2006. In: Buhlungu, S., Daniel, J., Southall, R. and Lutchman, J. (eds) State of the nation South Africa 2007 (pp. 114-145). Cape Town: HRSC Press.

Schulz-Herzenberg, C. and Southall, R. (eds) (2014) Election 2014: The campaigns, results and future prospects. Johannesburg: Jacana Publishers.

Smoke, P. (2003) Decentralisation in Africa: Goals, dimensions, myths and challenges. Public Administration and Development, 23, 7-16. doi: https://doi.org/10.1002/pad.255

South African Broadcast Corporation. (2016) Voter turnout drops in 2016 local government elections. (5 August 2016). Available at: http://www.sabc.co.za/news/a/9fa2bc004dc1bd28be2bbf359257e443/Voter-turnoutdrops-in-2016-local-government-elections-20160508 [Accessed November 2016].

South African Local Government Association. (2006) A handbook for municipal councilors. South Africa: Global Print Publisher.

Southall, R. (2007) Introduction: The ANC state, more dysfunctional than developmental? In: Buhlungu, S., Daniel, J., Southall, R. and Lutchman, J. (eds) State of the nation: South Africa 2007 (pp. 1-24). Cape Town: HRSC Press. doi: https://doi.org/10.1163/ej.9789004157897.i-264.6

Southall, R. (2013) Liberation movements in power: Party and state in Southern Africa. Pietermaritzburg UKZN Press. 
Southall, R. and Daniel, J. (2009) Zunami: The 2009 South African elections. Johannesburg: Jacana Media Publishers.

Staniland, L. (2008) They know me, I will not get a Job: Public participation, patronage and the sedation of civil society in Captetonian township. Transformation: Critical Perspectives on Southern Africa, 66, 34-60. doi: https://doi.org/10.1353/trn.0.0005

Suttner, R. (2009) The challenge to African National Congress dominance. Representation, 45 (5), $109-123$. doi: https://doi.org/10.1080/00344890902944346

The Guardian. (2016) South Africa's local election shock down to anger and apathy. (5 August 2016). Available at: https://www.theguardian.com/world/2016/aug/05/anger-and-apathy-behind-south-africas-shocklocal-election. [Accessed November 2015].

Thedvall, R. (2006) Eurocrats at work. Negotiating transparency in post-national employment policy. Journal of Social Anthropology, 58 (2).

Thedvall, R. (2013) Punctuated entries: Doing fieldwork in policy meetings in the European Union. In: Garsten, C. and Nyqvist, A. (eds) Organisational ethnography: Doing ethnography in and among complex organizations (pp. 114-137). London: Palgrave Macmillan.

Therkildsen, O. (2014) Working in neopatrimonial settings: Public sector staff perceptions in Tanzania and Uganda. In: Bierschenk, T. and Olivier de Sardan, J.P. (eds) States at work: Dynamics of African bureaucracies (pp. 113-144). Leiden: Brill. doi: https://doi.org/10.1163/9789004264960_006

Van Hulst, M.J. (2008) Quite an experience: Using ethnography to study local government. Critical Policy Analysis, 2 (2), 143-59. doi: https://doi.org/10.1080/19460171.2008.9518535

Von Holdt, K. (2010) The South African post-apartheid bureaucracy: Inner workings, contradictory rationales and the developmental state. In: Edigheji, O. (ed) Constructing a developmental state in South Africa: Potentials and challenges (pp. 275-291). Cape Town: HSRC Press.

Von Holdt, K., Langa, M., Molapo, S., Mogapi, N., Ngubeni, K., Dlamini, J. and Kirsten, A. (2011) The smoke that calls: Insurgent citizenship, collective violence and the struggle for a place in the new South Africa. Johannesburg: Centre for the Study of Violence and Reconciliation/Society, Work and Development Institute.

Ybema, S. and Kamsteeg, F. (2009) Making the familiar strange: A case for disengaged organizational ethnography. In: Ybema, S, Yanow, D., Wels, H. and Kamsteeg, F. (2009) Organizational ethnography: studying the complexities of everyday life. (pp. 101-119). London: Sage Publications. doi: https://doi.org/10.4135/9781446278925 and https://doi.org/10.4135/9781446278925.n6

Yin, R.K. (1989) Case study research: design and methods. Newbury Park, CA: Sage. 